ВІСНИК

ОДЕСЬКОГО НАЦІОНАЛЬНОГО

МОРСЬКОГО УНІВЕРСИТЕТУ

№ 2 (59), 2019
HERALD

OF THE ODESSA NATIONAL

MARITIME UNIVERSITY

№ 2 (59), 2019

УДК 656.615.078.111/117:656.07

DOI 10.33082/2226-1915 -2-2019-183-198

\title{
ОБГРУНТУВАННЯ МЕТОДИКИ ПЛАНУВАННЯ \\ ПІДВЕДЕННЯ ЗАЛІЗНИЧНИХ ВАГОНІВ У ТРАНСПОРТНІ ВУЗЛИ ПІД МОРСЬКІ СУДНА
}

\author{
А.О. Мурадь'ян \\ к.т.н., доцент кафедри «Експлуатація портів і технологія вантажних робіт» \\ С.С. Русанова \\ асистент кафедри «Експлуатація портів і технологія вантажних робіт»
}

Одеський національний морський університет

Анотація. Формування транспортних логістичних ланцюгів на основі календарного планування завантаження $i$ підведення вагонів 6 транспортний вузол під морські судна є одним з основних завдань регіонального транспортно-логістичного иентру [1-3]. Необхідність розробки методики календарного планування для иієї мети диктується недосконалістю існуючих підходів до взаємодії залізничного транспорту з морським, які трунтуються на стереотипі, щзо для виключення простою вагонів на підходах до порту досить забезпечити їх рівномірне підведення залізницею в кількості, що не перевищує можливості вантажнорозвантажувальних машин і механізмів порту.

Ключові слова: транспортний вузол, календарний план, взаємодія, транспортно-логістичний центр, транспортно-логістичні ланщңюги.

УДК 656.615.078.111 / 117: 656.07

DOI 10.33082/2226-1915 -2-2019-183-198

\section{ОБОСНОВАНИЕ МЕТОДИКИ ПЛАНИРОВАНИЯ ПОДВЕДЕНИЯ ЖЕЛЕЗНОДОРОЖНЫХ ВАГОНОВ В ТРАНСПОРТНЫЕ УЗЛЫ ПОД МОРСКИЕ СУДА}

А.О. Мурадьян

к.т.н., доцент кафедры «Эксплуатация портов и технология грузовых работ» С.С. Русанова

ассистент кафедры «Эксплуатаця портов и технология грузовых работ»

Одесский начиональный морской университет

Аннотация. Формирование транспортных логистических цеепей на основе календарного планирования загрузки и подведения вагонов в транспортный узел под морские суда является одной из основных задач регионального транспортно-логистического цчентра [1-3].

(C) Мурадь'ян А.О., Русанова С.С., 2019 
Необходимость разработки методики календарного планирования для этой цели диктуется несовершенством существующих подходов $\kappa$ взаимодействию железнодорожного транспорта с морским, которые основываются на стереотипе, что для исключения простоя вагонов на подходах к порту достаточно обеспечить их равномерное подведение железной дорогой в количестве, не превышающем возможности погрузочно-розгрузочних машин и механизмов порта.

Ключевые слова: транспортный узел, календарный план, взаимодействие, транспортно-логистический центр, транспортно-логистические иепи.

UDC 656.615.078.111/117:656.07

DOI 10.33082/2226-1915 -2-2019-183-198

\title{
RATIONALE THE METHOD OF PLANNING THE RAILWAYWAGONS APPROACH TO TRANSPORT HUBS UP TO SEA VESSELS
}

\author{
A. Murad'yan
}

Ph.D., Associate Professor of the Department «Port Operation and freight technology»

\section{S. Rusanova}

Assistant of the department «Port Operation and freight technology»

\section{Odessa National Maritime University}

Abstract. Formation of transport logistics chains on the basis of the scheduling of loading and bringing wagons into the transport hub under ships is one of the main tasks of the regional transport and logistics center [1-3]. The need to develop a scheduling methodology for this purpose is dictated by the imperfection of existing approaches to the interaction of railway transport with maritime, which are based on the stereotype that to exclude idle wagons at the approaches to the port, it is sufficient to ensure their uniform supply by rail, not exceeding the weight and port mechanisms.

Keywords: transport hub, calendar plan, interaction, transport and logistics center, transport and logistics chains.

Базовою основою методики календарного планування завантаження пропонуємо прийняти принцип узгодженого підведення вантажу залізницею в розмірі суднової партії, що формується на стадії планування завантаження на станціях відправлення під певне судно, що прибуває до порту в попередньо призначений термін $[4 ; 5]$.

Опис задачі. Необхідно розробити календарний план підведення вагонів з конкретним вантажем від станцій завантаження на адресу порту в обсязі суднової партії в часовий інтервал завантаження конкретного судна, що прибуває в конкретний час. Побудова календарного плану 
здійснюється за умови задоволення вектору техніко-технологічних критеріїв оптимальності $\overline{\kappa_{2}}=\left\{\kappa_{21}, K_{22}\right\}$.

Критерій $\mathrm{K}_{21}$ визначає, що добова кількість вантажу, який прибуває до порту залізничним транспортом за кожен день календарного періоду, не повинна перевищувати максимальну переробну спроможність вантажно-розвантажувальних машин порту, призначених для перевантаження даного вантажу

$$
\sum_{\mathrm{d}=1}^{\mathrm{S}} \mathrm{Q}_{\mathrm{d}}=\mathrm{q} \cdot \sum_{\mathrm{d}=1}^{\mathrm{S}} \mathrm{N}_{\mathrm{d}} \leq \sum_{\mathrm{j}=1}^{\mathrm{m}} \Pi_{\mathrm{j}} \cdot \mathrm{k}_{\mathrm{j}}
$$

де $\mathrm{Q}_{\mathrm{d}}$ - кількість вантажу, перевантаженого на судно в d-й день пері оду, т;

$$
\mathrm{d}=\overline{1, \mathrm{~s}} \text {; }
$$

$\mathrm{s}$ - число днів періоду календарного плану; $\mathrm{N}_{\mathrm{d}}$ - добова кількість вагонів, які прибувають в d-й день періоду;

q - технічна норма завантаження вагона, т/вагон;

$\Pi_{\mathrm{j}}$ - продуктивність ј-ої вантажно-розвантажувальної машини, т/добу;

$\mathrm{k}_{\mathrm{j}}$ - кількість $\mathrm{j}$-х вантажно-розвантажувальних машин;

$\mathrm{j}=\overline{1, \mathrm{~m}}, \mathrm{~m}$ - загальна кількість вантажно-розвантажувальних машин, які здійснюють перевантаження вантажу в дане судно.

Відповідно до критерію $\mathrm{K}_{22}$ сумарна кількість вантажу, що підводиться за весь період залізничним транспортом, має забезпечувати повне завантаження судна і перебувати в межах, визначених умовою

$$
\mathrm{Q}_{\text {підв }}^{\text {с.п. }} \leq \mathrm{Q}_{\text {підв }}^{\text {з.д. }} \leq \mathrm{Q}_{\text {судн }},
$$

де $\mathrm{Q}_{\text {підв }}^{\text {сп. }}=\mathrm{Q}_{\text {судн }}-\mathrm{Q}_{\text {причал }}-\mathrm{Q}_{\text {ваг }}^{\mathrm{oq}}-$ необхідна кількість вантажу, що підводиться за весь період залізничним транспортом для забезпечення завантаження суднової партії, т;

$\mathrm{Q}_{\text {судн }}$ - вантажопідйомність судна, т;

$\mathrm{Q}_{\text {причал }}$ - кількість вантажу для даного судна, що знаходиться на складських площах порту, т;

$\mathrm{Q}_{\text {ваг }}^{\text {оч }}$ - кількість вантажу в вагонах, що простоюють в очікуванні вивантаження на підходах до порту, т;

$$
\mathrm{Q}_{\text {підв }}^{\text {3.д. }}=\sum_{\mathrm{d}=1}^{\mathrm{S}} \mathrm{Q}_{\mathrm{d}}=\mathrm{q} \cdot \sum_{\mathrm{d}=1}^{\mathrm{S}} \mathrm{N}_{\mathrm{d}}-\text { сумарна кількість вантажу, що підводиться }
$$
за весь період залізничним транспортом, т. 
У загальному випадку значення функції експлуатаційних витрат, пов'язаних 3 непродуктивним простоєм вагонів 3 вантажем на припортовій станції і на підходах до неї в очікуванні судна і простоєм суден в порту в очікуванні вантажу, має бути мінімальним

$$
\mathrm{F}\left\{e_{\text {ваг-час }} \sum_{\mathrm{d}=1}^{\mathrm{S}} N_{\mathrm{d}} T_{\text {ваг }}^{o u} ; e_{c y \partial н о-ч а с)} \cdot \sum_{\mathrm{d}=1}^{\mathrm{S}} \mathrm{T}_{c y \partial \mu \mathrm{d}}^{n p}\right\} \rightarrow \min ,
$$

де $\sum_{\mathrm{d}=1}^{\mathrm{S}} \mathrm{N}_{\mathrm{d}} \mathrm{T}_{\text {ваг }}^{\text {ou }}$ - сумарні години простою вагонів на підходах до порту в очікуванні вивантаження, вагоно-години;

$e_{\text {ваг-час }}-$ вартість однієї години простою вагона, грн.;

$\sum_{\mathrm{d}=1}^{\mathrm{S}} \mathrm{T}_{c y \partial \mathrm{d}_{\mathrm{d}}}^{n p}$ - сумарні години непродуктивного простою судна в порту в очікуванні вантажу, судно-години;

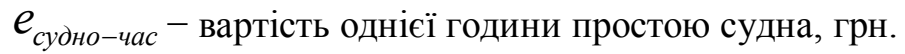

Математичні методи розв'язання задачі. Залежно від виду вихідних даних і обмежень, що вводяться у задачі, може вирішуватися різними методами. У даній статті задача формулюється в рамках лінійного програмування і комбінаторної глобальної оптимізації. У першому формулюванні задачі використовуються методи лінійного програмування. Задачі лінійного програмування добре вивчені, для їх вирішення розроблені ефективні методи, зокрема, симплекс-метод.

Разом 3 тим, часто доводиться стикатися з ситуаціями, коли вартість перевезення вантажів залежить від його кількості, тоді задача стає нелінійною. У цьому випадку доцільно використовувати метод глобальної комбінаторної оптимізації, серед них найбільш простий - метод прямого перебору. Цей метод може бути використаний при вирішенні нескладних задач або при наявності обмежень, що значно скорочують число можливих варіантів рішення. У задачах $з$ досить великою кількістю обмежень можливо тривіальне рішення, що дозволяє отримувати цілочисельні значення вихідних параметрів на основі нескладних алгоритмів. Якщо задача має велику складність, то можуть застосовуватися наближені методи або ж поєднання математичних і евристичних методів [6-8].

Нехай $\mathrm{N}_{\text {id }}-$ кількість вагонів, які прибули з вантажем від і-ої станції завантаження;

$$
\mathrm{i}=\overline{1, \mathrm{n}, \mathrm{n}} \text { - загальне число станцій завантаження, в } \mathrm{d} \text { - й день }
$$
вивантаження в порту;

$\mathrm{d}=\overline{1, \mathrm{~s}}, \mathrm{~s}-$ число днів вивантаження (календарного плану);

$\mathrm{c}_{\mathrm{i}}$ - вартість вантажу, що прибув зі станції з номером $\mathrm{i}$. 
Якщо фактор вартості вантажу не враховується, то вона приймається однаковою для всіх станцій. Можливо є певна кількість вагонів $\mathrm{N}_{\text {ваг }}^{\text {оч }}$, що очікують завантаження з різними датами прибуття на станцію призначення. Якщо ця кількість вагонів не може бути перевантажена на морське судно протягом одного дня, то $\mathrm{N}_{\text {ваг }}^{\text {оч }}$ розбивається на множину $\left\{\mathrm{N}_{\mathrm{d}}^{\text {оч.ваг }}\right\}, \sum_{\mathrm{d}=1}^{\mathrm{s}} \mathrm{N}_{\mathrm{d}}^{\text {оч.ваг }}=\mathrm{N}_{\text {ваг }}^{\text {оч }}$. Слід підкреслити, що деякі або всі $\mathrm{N}_{\mathrm{d}}^{\text {оч.ваг }}$ можуть бути рівними нулю. Вартості вантажів в очікуємих вагонах $\mathrm{c}_{\mathrm{d}}^{\text {оч.ваг }}, \mathrm{d}=\overline{1, \mathrm{~s}}$, задаються наступним чином:

$$
\mathrm{c}_{\mathrm{d}}^{\text {оч.ваг }}<\mathrm{kc}_{\mathrm{d}+1}^{\text {оч.ваг }}, \mathrm{k} \approx 10, \forall \mathrm{d}=\overline{1, \mathrm{~s}-1}
$$

Ця умова буде сприяти плануванню розвантаження вагонів. Крім цього необхідно забезпечити умови узгодження з об'ємом суднової партії, $\sum_{\mathrm{d}=1 \mathrm{i}=1}^{\mathrm{s}} \sum_{\mathrm{id}}^{\mathrm{n}} \mathrm{N}_{\mathrm{id}}=\mathrm{N}_{\text {судн }}-\mathrm{N}_{\text {ваг }}^{\mathrm{oq}}$. Друга вимога - щодобове прибуття необхідного числа вагонів (в обсязі 1/s від суднової партії) протягом календарного плану на припортову станцію для перевантаження: $\sum_{\mathrm{i}=1}^{\mathrm{n}} \mathrm{N}_{\mathrm{id}}=\frac{\mathrm{N}_{\text {судн }}}{\mathrm{S}}-\mathrm{N}_{\mathrm{d}}^{\text {oч.ваг. }}$. Наступна вимога - кожна станція завантаження в будь-який день календарного плану може завантажити кілька вагонів у допустимий (або бажаний за технологічними умовами) інтервал

$$
\mathrm{N}_{\mathrm{id}}^{\min } \leq \mathrm{N}_{\mathrm{id}} \leq \mathrm{N}_{\mathrm{id}}^{\max }
$$

Сумарно кожна станція завантаження за весь період відвантажує певне число вагонів

$$
\sum_{\mathrm{d}=1}^{\mathrm{S}} \mathrm{N}_{\text {id }}=\mathrm{N}_{\mathrm{i}}, \forall \mathrm{i}=\overline{1, \mathrm{n}}
$$

Можливий варіант обов'язкового виконання за обсягом, тоді

$$
\mathrm{N}_{\text {id }}^{\min }=\mathrm{N}_{\mathrm{id}}^{\max }=\mathrm{N}_{\text {id }} .
$$

Таким чином, математичне формулювання задачі полягає в тому, щоб знайти $\mathrm{N}_{\mathrm{id}}\left(\mathrm{N}_{\mathrm{i}}, \mathrm{N}_{\mathrm{d}}^{\text {оч.ваг }}\right.$ залежать від $\left.\mathrm{N}_{\mathrm{id}}\right)$ 


$$
\left\{\begin{array}{l}
\sum_{\mathrm{d}=1 \mathrm{i}=1}^{\mathrm{s}} \sum_{\mathrm{i}}^{\mathrm{n}} \mathrm{c}_{\mathrm{i}} \mathrm{N}_{\mathrm{id}}+\sum_{\mathrm{d}=1}^{\mathrm{s}} \mathrm{c}_{\mathrm{d}}^{\text {оч.ваг }} \mathrm{N}_{\mathrm{d}}^{\text {oч.ваг }} \rightarrow \min , \\
\sum_{\mathrm{d}=1 \mathrm{i}=1}^{\mathrm{s}} \sum_{\mathrm{id}}^{\mathrm{n}} \mathrm{N}_{\mathrm{id}}=\mathrm{N}_{\text {суд }}-\mathrm{N}_{\text {вar }}^{\text {ou }}, \sum_{\mathrm{d}=1}^{\mathrm{s}} \mathrm{N}_{\mathrm{d}}^{\text {оч. ваг }}=\mathrm{N}_{\text {ваг }}^{\text {oч }}, \sum_{\mathrm{i}=1}^{\mathrm{n}} \mathrm{N}_{\mathrm{id}}=\frac{\mathrm{N}_{\text {судн }}}{\mathrm{S}}-\mathrm{N}_{\mathrm{d}}^{\text {oч. ваг }} \\
\sum_{\mathrm{d}=1}^{\mathrm{s}} \mathrm{N}_{\mathrm{id}}=\mathrm{N}_{\mathrm{i}}, \mathrm{N}_{\mathrm{id}}^{\mathrm{min}} \leq \mathrm{N}_{\mathrm{id}} \leq \mathrm{N}_{\mathrm{id}}^{\mathrm{max}} \\
\forall \mathrm{i}=\overline{1, \mathrm{n}} \mathrm{d}=\overline{1, \mathrm{~s}}
\end{array}\right.
$$

Сформульована задача вирішується методом лінійного програмування, для чого використовуються готові пакети програм вирішення завдань лінійного програмування, включаючи програми знаходження цілочисельних рішень.

Задача комбінаторної оптимізації складання розкладів. Математичне формулювання розглянутої целочисельної задачі $\epsilon$ дискретним варіантом задачі лінійного програмування і в даній постановці відноситься до задачі комбінаторної глобальної оптимізації. У загальному випадку розглянута задача відноситься до NP-повних задач і їі комбінаторна складність зростає експоненціально.

Регіональний транспортно-логістичний центр в загальному випадку має можливість вибору постачальників і обсягів вантажів в кожен день завантаження. У розглянутій постановці задачі кількість вагонів для завантаження на станціях допускається різною по днях календарного плану. Можливо, є певна кількість очікуємих вагонів $\mathrm{N}_{\text {ваг }}^{\text {ож }}$ з різними датами прибуття до станції призначення.

Перевезення здійснюється вагонами відповідно до технічної норми завантаження вагона q, час транспортування враховується в добі, обсяг суднової партії (в тоннах) ділиться без залишку на технічне завантаження вагону.

Нехай $\mathrm{N}_{\mathrm{d}}^{\mathrm{i}}$ - кількість вагонів, які прибули з вантажем від і-ої станції завантаження;

$\mathrm{i}=\overline{1, \mathrm{n}} \mathrm{n}$ - загальне число станцій завантаження в d-й день вивантаження в порту;

$\mathrm{d}=\overline{1, \mathrm{~s}} \mathrm{~s}-$ число днів вивантаження;

$\mathrm{c}_{\mathrm{i}}$ - вартість вантажу, що прибув з і-ої станції.

Якщо вартість $\mathrm{c}_{\mathrm{i}}$ залежить від обсягу вантажу, що перевозиться $\mathrm{c}_{\mathrm{i}}\left(\mathrm{N}_{\mathrm{d}}^{\mathrm{i}}\right)$, то в цьому випадку розглянута задача $\epsilon$ нелінійною, для вирішення якої пропонується використовувати метод простого перебору. Якщо фактор вартості вантажу не потрібно враховувати, то вартість приймається однаковою для всіх станцій. Враховується, що, можливо, є 
певна кількість вагонів $\mathrm{N}_{\text {ваг }}^{04}$, що очікують завантаження з різними датами прибуття на станцію призначення. Якщо ця кількість вагонів не може бути перевантаженою на морське судно протягом одного дня, розбивається на безліч $\left\{\mathrm{N}_{\mathrm{d}}^{\text {oq.ваг }}\right\}, \sum_{\mathrm{d}=1}^{\mathrm{s}} \mathrm{N}_{\mathrm{d}}^{\text {oq.ваг }}=\mathrm{N}_{\text {ваг }}^{\text {oч }}$. Слід підкреслити, що деякі або всі $\mathrm{N}_{\mathrm{d}}^{\text {oq.ваг }}$ можуть бути рівними нулю. Вартість вантажів в вагонах, що очікують $\mathrm{c}_{\mathrm{d}}^{\text {оч.ваг }}, \mathrm{d}=\overline{1, \mathrm{~s}}$ задаються наступним чином:

$$
\mathrm{c}_{\mathrm{d}}^{\text {оч.ваг }}<\mathrm{kc}_{\mathrm{d}+1}^{\text {оч.ваг }}, \mathrm{k} \approx 10, \forall \mathrm{d}=\overline{1, \mathrm{~s}-1} \text {. }
$$

Ця умова буде сприяти плануванню розвантаження вагонів, що очікують, в першу чергу. Крім цього необхідно забезпечити умови узгодження з об'ємом суднової партії

$$
\sum_{\mathrm{d}=1}^{\mathrm{s}} \sum_{\mathrm{i}=1}^{\mathrm{n}} \mathrm{N}_{\mathrm{id}}=\mathrm{N}_{\text {судн }}-\mathrm{N}_{\text {ваг }}^{\text {оч }}
$$

Друга вимога - прибуття необхідного числа вагонів в кожен день завантаження

$$
\sum_{\mathrm{i}=1}^{\mathrm{n}} \mathrm{N}_{\mathrm{d}}^{\mathrm{i}}=\frac{\mathrm{N}_{\text {судн }}}{S}-\mathrm{N}_{\mathrm{d}}^{\text {оч.ваг }}
$$

Наступна вимога - кожна станція завантаження може завантажити кілька вагонів із допустимого набору цілих величин

$$
\mathrm{N}_{\mathrm{d}}^{\mathrm{i}} \in \mathrm{N}^{\mathrm{m}}, \mathrm{N}^{\mathrm{m}}=\left\{\mathrm{N}_{\mathrm{d}}^{\mathrm{i}}\right\}
$$

де $\mathrm{N}^{\mathrm{m}}$ - безліч можливих або бажаних значень (включаючи нуль) завантажуємих вагонів для кожного дня на кожній станції завантаження. Величина $\mathrm{N}^{\mathrm{m}}$ може складатися тільки з одного числа, що фіксує кількість відвантажених вагонів в певний день (або дні, або всі дні деякої станції). Сумарно кожна станція завантаження за весь період відвантажує певну кількість вагонів

$$
\sum_{\mathrm{d}=1}^{\mathrm{s}} \mathrm{N}_{\mathrm{d}}^{\mathrm{i}}=\mathrm{N}_{\mathrm{i}}, \forall \mathrm{i}=\overline{1, \mathrm{n}}
$$

Таким чином, математичне формулювання завдання полягає в тому, щоб

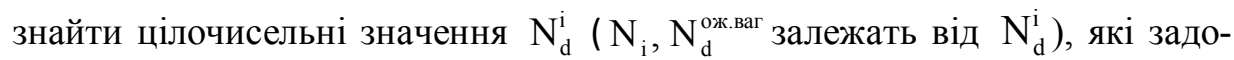
вольняють 


$$
\left\{\begin{array}{c}
\sum_{\mathrm{d}=1 \mathrm{i}=1}^{\mathrm{s}} \sum_{\mathrm{d}=1}^{\mathrm{n}} \mathrm{c}_{\mathrm{i}} \mathrm{N}_{\mathrm{d}=1}^{\mathrm{i}}+\sum_{\mathrm{d}=1}^{\mathrm{s}} \mathrm{c}_{\mathrm{d}}^{\text {oч. ваг }} \mathrm{N}_{\mathrm{d}}^{\text {oч. ваг }} \rightarrow \min , \\
\sum_{\mathrm{d}}^{\mathrm{s}} \sum_{\text {судн }}^{\mathrm{n}} \mathrm{N}_{\mathrm{Bar}}^{\mathrm{i}}, \mathrm{N}_{\mathrm{d}=1}^{\mathrm{s}} \mathrm{N}_{\mathrm{d}}^{\text {oч. ваг }}=\mathrm{N}_{\text {ваг }}^{\text {oж }}, \sum_{\mathrm{i}=1}^{\mathrm{n}} \mathrm{N}_{\mathrm{d}}^{\mathrm{i}}=\frac{\mathrm{N}_{\text {судн }}}{\mathrm{S}}-\mathrm{N}_{\mathrm{d}}^{\text {oч. ваг }} \\
\sum_{\mathrm{d}=1}^{\mathrm{s}} \mathrm{N}_{\mathrm{d}}^{\mathrm{i}}=\mathrm{N}_{\mathrm{i}}, \quad \mathrm{N}_{\mathrm{d}}^{\mathrm{i}} \in \mathrm{N}^{\mathrm{m}}, \\
\forall \mathrm{i}=\overline{1, \mathrm{n}}, \mathrm{d}=\overline{1, \mathrm{~s}}, \quad \mathrm{~N}_{\text {судн }}, \mathrm{N}_{\mathrm{i}}, \mathrm{N}_{\mathrm{d}}^{\mathrm{i}} \in \mathrm{Z}
\end{array}\right.
$$

тут $Z$ - безліч цілих чисел.

Метод перебору годиться для невеликих розмірностей завдань. Обчислювальна складність методу перебору залежить від діапазону можливих перебираємих значень. Якщо таких значень 5, то для 4 днів $\mathrm{i}$ 3 станцій перебираємих комбінацій буде $5^{12} \approx 2.4 \cdot 10^{8}$, що дозволить знайти рішення на сучасному комп'ютері за одну секунду. Для 5 днів $\mathrm{i}$ 4 станцій це число дорівнюватиме $5^{20} \approx 9.5 \cdot 10^{13}$, що вже приведе до значних обчислювальних витрат. Тому для скорочення кількості розрахунків необхідно ставити обмеження мінімальної кількості вагонів, що відвантажуються на станціях відправлення (наприклад, не менше одного маршрута на добу). У кожному конкретному випадку це обмеження вибирається індивідуально.

Алгоритм складання календарного плану завантаження. Календарний план завантаження являє собою кінцеву безліч добових розкладів завантаження вагонів 3 даним вантажем 3 різних навантажувальних станцій з вказівкою кількості відвантаженого вантажу, дати його відправлення і прибуття на припортову станцію [9-10]

$$
\overline{\mathrm{P}}=\left\{\left(\mathrm{p}_{\mathrm{i} 1}+\mathrm{p}_{\mathrm{i} 2}+\ldots+\mathrm{p}_{\mathrm{is}} \mid \mathrm{i}=\overline{1, \mathrm{n}}, \mathrm{p}_{\mathrm{i} 1} \in \mathrm{P}_{1}, \mathrm{p}_{\mathrm{i} 2} \in \mathrm{P}_{2}, \ldots, \mathrm{p}_{\mathrm{is}} \in \mathrm{P}_{\mathrm{s}}\right\},\right.
$$

де $\overline{\mathrm{P}}$ - календарний план завантаження;

$\mathrm{P}_{1}, \mathrm{P}_{2}, \ldots, \mathrm{P}_{\mathrm{s}}-$ розклад завантаження по днях календарного плану;

$\mathrm{S}$ - число днів завантаження (період календарного плану);

$\mathrm{p}_{\mathrm{i} 1}, \mathrm{p}_{\mathrm{i} 2}, \ldots, \mathrm{p}_{\mathrm{is}}-$ добові розклади завантаження i-ої станції по днях календарного плану;

n - загальне число станцій, що беруть участь у завантаженні вагонів для конкретного судна.

Добовий розклад завантаження i-ої станції призначенням на $\mathrm{d}$-й день календарного плану $\mathrm{p}_{\text {id }}$ може бути представлено в наступному вигляді: 


$$
\mathrm{p}_{\mathrm{id}}=f\left(\mathrm{Q}_{\mathrm{id}}, \mathrm{t}_{\mathrm{id}}^{\mathrm{Bi}}\right)
$$

де $\mathrm{Q}_{\text {id }}-$ добове завантаження i-ої станції з прибуттям на припортову станцію в d-й день календарного плану, т;

$\mathrm{t}_{\mathrm{id}}^{\text {вiдпр }}$ - дата відправлення вагонів з $\mathrm{i}$-ої станції завантаження з прибуттям в d-й день календарного плану.

Розробка календарного плану здійснюється поетапно і включає в себе визначення сукупності нормоутворюючих параметрів

$$
\mathrm{T}_{\text {кп }}, \mathrm{Q}_{\mathrm{id}}, \mathrm{t}_{\mathrm{d}}, \mathrm{t}_{\mathrm{id}}^{\mathrm{Biдпр}}, \mathrm{t}_{\mathrm{id}}^{\text {пр }},
$$

тобто

$$
\mathrm{K} \Pi=\left\{\mathrm{T}_{\text {кп }}, \mathrm{Q}_{\mathrm{id}}, \mathrm{t}_{\mathrm{d}}, \mathrm{t}_{\mathrm{id}}^{\mathrm{siдnр}}, \mathrm{t}_{\mathrm{id}}^{\mathrm{\Pi p}}\right\},
$$

де $\mathrm{T}_{\text {кп }}$ - період календарного плану, доба;

$\mathrm{Q}_{\mathrm{id}}$ - добове завантаження i-ої станції в d-й день календарного плану, т;

$$
\mathrm{i}=\overline{1, \mathrm{n}}, \mathrm{d}=\overline{1, \mathrm{~s}}
$$

при цьому $\mathrm{Q}_{\mathrm{id}} \in \mathrm{Q}_{\text {судн }}, \sum_{\mathrm{d}=1}^{\mathrm{s}} \sum_{\mathrm{i}=1}^{\mathrm{n}} \mathrm{Q}_{\mathrm{id}}=\mathrm{Q}_{\text {підв }}^{\text {з.д. }}-$ сумарне завантаження 3 усіх станцій відправлення за весь період календарного плану, т; $\mathrm{t}_{\mathrm{i}}$ - час ходу от i-ої станції завантаження до порту призначення, діб; $\mathrm{t}_{\mathrm{id}}^{\mathrm{siдnр}}$ - безліч моментів відправлення вагонів зі станцій завантаження; $\mathrm{t}_{\mathrm{id}}^{\text {пр }}$ - безліч моментів прибуття вагонів в порт призначення в період календарного плану, при цьому $\mathrm{t}_{\mathrm{id}}^{\text {пр }} \in \mathrm{T}_{\text {кп }}$.

Необхідно відзначити, що недостатня площа складів в портах не дозволяє забезпечувати накопичення вантажів в розмірі суднових партій в нормальному режимі зберігання і призводить до того, що при виникненні непередбачених обставин може мати місце непродуктивний простій вагонів в очікуванні вивантаження $\mathrm{T}_{\text {ваг }}^{\text {оч }}$. Тому запропонована методика розробки календарного плану завантаження 3 метою забезпечення можливості її використання в практичній діяльності в загальному вигляді враховує ці витрати. Потрібно знайти $\mathrm{Q}_{\text {id }}$, що задовольняють 


$$
\left\{\begin{array}{c}
\sum_{\mathrm{d}=1}^{\mathrm{s}} \sum_{\mathrm{i}=1}^{\mathrm{n}} \mathrm{Q}_{\mathrm{id}}=\mathrm{Q}_{\text {судн }}-\mathrm{Q}_{\text {ваг }}^{\text {оч }}, \\
\sum_{\mathrm{d}=1}^{\mathrm{s}} \mathrm{Q}_{\mathrm{d}}^{\text {оч. ваг }}=\mathrm{Q}_{\text {ваг }}^{\text {оч }}, \\
\sum_{\mathrm{i}=1}^{\mathrm{n}} \mathrm{Q}_{\mathrm{id}}=\frac{\mathrm{Q}_{\text {судн }}}{S}-\mathrm{Q}_{\mathrm{d}}^{\text {оч.ваг }}, \\
\sum_{\mathrm{d}=1}^{\mathrm{s}} \mathrm{Q}_{\mathrm{id}}=\mathrm{Q}_{\mathrm{i}}, \quad \forall \mathrm{i}=\overline{1, \mathrm{n}}, \quad \mathrm{d}=\overline{1, \mathrm{~s}}
\end{array}\right.
$$

де $\mathrm{Q}_{\mathrm{id}}$ - завантаження i-ої станції в d-й день розвантаження, т;

$\mathrm{Q}_{\text {судн }}$ - суднова партія, т;

$\mathrm{Q}_{\text {ваг }}^{\text {оч }}$ весь вантаж в вагонах, що очікують, т;

$\mathrm{Q}_{\mathrm{d}}^{\text {oч. ваг }}$ - вантаж в вагонах, що очікують, які розвантажуються в $\mathrm{d}$-й день розвантаження, т;

$\mathrm{Q}_{\mathrm{i}}$ - загальна маса вантажу від i-ої станції, т.

Формування календарного плану завантаження спільного підведення вагонів і судна здійснюється поетапно.

1 этап. Визначається період календарного плану. Загальний час завантаження судна знаходиться за формулою

$$
\mathrm{T}_{\text {судн }}=\frac{\mathrm{Q}_{\text {судн }}}{\sum_{\mathrm{j}=1}^{\mathrm{m}} \Pi_{\mathrm{j}} \cdot \mathrm{k}_{\mathrm{j}}},
$$

Цей період включає в себе тимчасові витрати, пов'язані з виконанням вантажно-розвантажувальних операцій з вантажами, що знаходяться на причалі; в вагонах, які очікують вивантаження на припортовій станції і на підходах до неї; в вагонах, наступних для вивантаження в порт

$$
\mathrm{T}_{\text {судн }}=\mathrm{T}_{\text {прич }}+\mathrm{T}_{\text {ваг }}^{\text {оч }}+\mathrm{T}_{\text {підв }}^{\text {с.п. }}
$$

де $\mathrm{T}_{\text {причал }}$ - тривалість перевантаження вантажу, що знаходиться на причалах порту

$$
\mathrm{T}_{\text {прич }}=\frac{\mathrm{Q}_{\text {прич }}}{\sum_{\mathrm{j}=1}^{\mathrm{m}} \Pi_{\mathrm{j}} \cdot \mathrm{k}_{\mathrm{j}}},
$$

$\mathrm{T}_{\text {ваг }}^{\text {оч }}$ - тривалість перевантаження вантажу, що знаходиться в вагонах в очікуванні вивантаження

$$
\mathrm{T}_{\text {Bar }}^{\text {ou }}=\frac{\mathrm{Q}_{\text {Bar }}^{\text {ou }}}{\sum_{\mathrm{j}=1}^{\mathrm{m}} \Pi_{\mathrm{j}} \cdot \mathrm{k}_{\mathrm{j}}},
$$


$\mathrm{T}_{\text {подв }}^{\text {с.п }}-$ період часу, протягом якого необхідно підвести вагони з вантажем для забезпечення завантаження суднової партії

$$
\mathrm{T}_{\text {подв }}^{\text {спп. }}=\frac{\mathrm{Q}_{\text {подв }}^{\text {сп. }}}{\sum_{\mathrm{j}=1}^{\mathrm{m}} \Pi_{\mathrm{j}} \cdot \mathrm{k}_{\mathrm{j}}}=\frac{\mathrm{Q}_{\text {судн }}-\left(\mathrm{Q}_{\text {причал }}+\mathrm{Q}_{\text {ваг }}^{\text {оч }}\right)}{\sum_{\mathrm{j}=1}^{\mathrm{m}} \Pi_{\mathrm{j}} \cdot \mathrm{k}_{\mathrm{j}}} .
$$

Період часу, протягом якого може бути здійснено завезення вантажу, визначається технологією роботи порту.

А. Якщо в порту причали спеціалізовані за родами і марками вантажу, то загальна кількість вантажу, що підвозиться залізничним транспортом $\mathrm{Q}_{\text {підв }}^{\text {з.д. }}$, складає

$$
\mathrm{Q}_{\text {підв }}^{\text {3.д. }}=\mathrm{Q}_{\text {підв }}^{\text {с.п. }}+\mathrm{Q}_{\text {причал }}-\mathrm{Q}_{\text {ваг }}^{\text {оч }} .
$$

Пов'язано це $з$ тим, що причал звільняється повністю і потрібно його заповнити для наявності певного резерву, що реалізується при підході судна заданим вантажем. У цьому випадку період часу $\mathrm{T}_{\text {кп }}$, протягом якого необхідно підвести вагони з вантажем, визначається за формулою

$$
\mathrm{T}_{\text {кп }}=\mathrm{T}_{\text {пाдв }}^{\text {с.п. }}+\mathrm{T}_{\text {причал }}-\mathrm{T}_{\text {ваг }}^{\text {оч }} .
$$

Б. Якщо ж причали порту не спеціалізовані, то загальна кількість вантажу, що підвозяться для завантаження судна, становить

$$
\mathrm{Q}_{\text {підв }}^{\text {3.д. }}=\mathrm{Q}_{\text {судн }}-\mathrm{Q}_{\text {ваг }}^{\text {оч }},
$$

В даному випадку попереднього накопичення вантажу на причалі

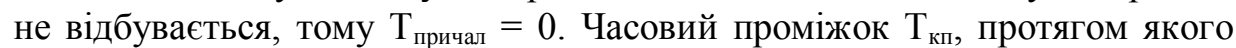
необхідно підвести вагони з вантажем, визначається за формулою

$$
\mathrm{T}_{\text {кп }}=\mathrm{T}_{\text {судн }}-\mathrm{T}_{\text {ваг }}^{\text {оч }},
$$

2 этап. Визначається добове завантаження по кожній станції відправлення по днях періоду календарного плану.

Для випадку рівномірного відвантаження по днях календарного плану

$$
\mathrm{Q}_{\mathrm{id}}=\frac{\mathrm{Q}_{\mathrm{i}}}{\mathrm{T}_{\text {кп }}},
$$

де $\mathrm{Q}_{\mathrm{id}}$ - завантаження i-ої станції на d-й день календарного плану;

$\mathrm{Q}_{\mathrm{i}}$ - загальна кількість вантажів, що відвантажуються і-ю станцією у рамках календарного плану. При цьому повинна виконуватися умова

$$
\sum_{\mathrm{d}=1}^{\mathrm{s}} \sum_{\mathrm{i}=1}^{\mathrm{n}} \mathrm{Q}_{\mathrm{id}}=\mathrm{Q}_{\text {підв }}^{\text {з.д }},
$$

За результатами розрахунку формується сукупність безлічі обсягів завантаження зі станцій відправлення, що представлена в таблиці 1. 
ВІСНИК

ОДЕСЬКОГО НАЦІОНАЛЬНОГО

МОРСЬКОГО УНІВЕРСИТЕТУ

№ 2 (59), 2019
HERALD

OF THE ODESSA NATIONAL

MARITIME UNIVERSITY

№ 2 (59), 2019

Таблиия 1

Таблиия безлічі обсягів завантаження зі станиій відправлення

\begin{tabular}{|c|c|c|c|c|}
\hline \multirow{2}{*}{ Станції завантаження } & \multicolumn{4}{|c|}{ Дні періоду календарного плану } \\
\cline { 2 - 5 } & 1 & 2 & $\ldots$ & $\mathrm{s}$ \\
\hline 1 & $\mathrm{Q}_{11}$ & $\mathrm{Q}_{21}$ & $\ldots$ & $\mathrm{Q}_{\mathrm{s} 1}$ \\
\hline 2 & $\mathrm{Q}_{12}$ & $\mathrm{Q}_{22}$ & $\ldots$ & $\mathrm{Q}_{\mathrm{s} 2}$ \\
\hline 3 & $\mathrm{Q}_{13}$ & $\mathrm{Q}_{23}$ & $\ldots$ & $\mathrm{Q}_{\mathrm{s} 3}$ \\
\hline$\ldots$ & $\ldots$ & $\ldots$ & $\ldots$ & $\ldots$ \\
\hline $\mathrm{n}$ & $\mathrm{Q}_{1 \mathrm{n}}$ & $\mathrm{Q}_{2 \mathrm{n}}$ & $\ldots$ & $\mathrm{Q}_{\mathrm{sn}}$ \\
\hline
\end{tabular}

3 этап. Визначається безліч моментів відправлення вагонів 3 вантажем зі станцій завантаження і їх прибуття в порт призначення. Для виконання умови чіткої взаємодії залізничного і морського транспорту, необхідно, щоб перші вагони почали надходити під перевантаження в порт після завершення вантажно-розвантажувальних операцій з вантажем на причалі, а також з вагонами, що знаходяться в очікуванні вивантаження на припортовий станції.

Дата надходження вагонів на припортову станцію Д погт визначається за формулою

$$
Д_{\text {ваг }}^{\text {пост }}=Д_{\text {судн }}^{\text {пр }}+\mathrm{T}_{\text {причал }}+\mathrm{T}_{\text {ваг }}^{\text {оч }}-\mathrm{t}_{\text {техн }},
$$

де Д судн

$\mathrm{t}_{\text {техн }}$ - тривалість виконання технологічних операцій в процесі передачі вагонів з вантажем на перевантаження в порт (маневрових, комерційних, приймально-здавальних і т. д.).

Для кожної станції відправлення встановлюється час ходу до пункту призначення з урахуванням подачі в порт за формулою

$$
t_{\mathrm{i}}=\frac{\mathrm{L}_{\mathrm{i}}}{\mathrm{V}},
$$

де $\mathrm{t}_{\mathrm{i}}$ - час ходу вагонів $з$ вантажем від $\mathrm{i}$-ої станції відправлення до порту призначення, діб;

$\mathrm{L}_{\mathrm{i}}$ - відстань перевезення від i-ої станції відправлення до пункту призначення, км;

$\mathrm{V}$ - середньодобова швидкість доставки, км/доба.

Таким чином, дата відправлення вагонів і-ої станції з прибуттям в d-й день календарного плану завантаження визначається за формулою

$$
\mathrm{t}_{\mathrm{id}}^{\mathrm{\text {iдmp }}}=Д_{\text {ваг }}^{\text {пост }}-\mathrm{t}_{\mathrm{i}},
$$

В результаті формується сукупність безлічі моментів відправлення вагонів зі станцій завантаження (формування маршрутів). 
Відповідні дані необхідні для організації відправлення вагонів зі станцій завантаження (формування маршрутів), то для організації просування вагонів з вантажем до порту призначення за принципом «точно в строк», необхідно сформувати сукупність безлічі моментів календарного прибуття вагонів на припортову станцію (таблиця 2).

Таблиия 2

Таблиия безлічі моментів календарного прибуття вагонів на припортову станиію

\begin{tabular}{|c|c|c|c|c|}
\hline \multirow{2}{*}{ Станції завантаження } & \multicolumn{4}{|c|}{ Моменти прибуття вагонів } \\
\cline { 2 - 5 } & 1 & 2 & $\cdots$ & $\mathrm{s}$ \\
\hline 1 & $\mathrm{t}_{11}^{\text {пр }}$ & $\mathrm{t}_{21}^{\text {пр }}$ & $\cdots$ & $\mathrm{t}_{\mathrm{s} 1}^{\text {пр }}$ \\
\hline 2 & $\mathrm{t}_{12}^{\text {пр }}$ & $\mathrm{t}_{22}^{\text {пр }}$ & $\cdots$ & $\mathrm{t}_{\mathrm{s} 2}^{\text {пр }}$ \\
\hline 3 & $\mathrm{t}_{13}^{\text {пр }}$ & $\mathrm{t}_{23}^{\text {пp }}$ & $\cdots$ & $\mathrm{t}_{\mathrm{s} 3}^{\text {пр }}$ \\
\hline$\ldots$ & $\ldots$ & $\ldots$ & $\ldots$ & $\ldots$ \\
\hline $\mathrm{n}$ & $\mathrm{t}_{1 \mathrm{n}}^{\text {пp }}$ & $\mathrm{t}_{2 \mathrm{n}}^{\text {пр }}$ & $\cdots$ & $\mathrm{t}_{\mathrm{sn}}^{\text {пp }}$ \\
\hline
\end{tabular}

В рамках методики календарного планування використовується суміщений алгоритм складання календарного плану, що поєднує в собі поетапний розрахунок з використанням методу комбінаторної глобальної оптимізації на стадії визначення добового навантаження по кожній станції відправлення і безлічі моментів відправлення вагонів з вантажем зі станцій завантаження, а також їх прибуття в порт призначення, що представляє собою цілочисельну NP-повну задачу, реалізовану у вигляді прямого перебору. Такий підхід дозволяє варіювати величиною числа вагонів, що відправляються зі станцій завантаження, при цьому в якості обмеження, значно скорочуючи обсяг обчислень, приймається продуктивність механізмів, зайнятих на виконанні вантажно-розвантажувальних робіт.

При цьому повинна виконуватися умова

$$
\mathrm{t}_{\mathrm{id}}^{\mathrm{mp}} \in \mathrm{T}_{\text {кп }}, \mathrm{d}=\overline{1, \mathrm{~s}} \quad \mathrm{i}=\overline{1, \mathrm{n}},
$$

4 этап. Формування календарного плану завантаження. У загальному вигляді процес побудови календарного плану у вигляді добових розкладів завантаження в межах $\mathrm{T}_{\text {кп }}$ може бути здійснений шляхом конструювання графа $(\mathrm{X}, \overrightarrow{\mathrm{U}})$, де X - безліч станцій завантаження (вершин), які здійснюють відправлення завантажених вагонів на адресу порту призначення, $\overrightarrow{\mathrm{U}}$ - безліч дуг. Побудова кожного розкладу передбачає заміну в неорієнтованому графі ребер дугами таким чином, щоб не утворювалося контурів. У підсумку кожному розкладу буде відповідати певний орієнтований безконтурний граф. 
Розроблений календарний план навантаження можна представити у вигляді об'ємної матриці, де наведено обсяги навантаження зі станцій відправлення і дати їх відправлення, а також дні календарного плану, в які здійснюється перевантаження прибулих вагонів на судно. Перетин відповідних $Q_{\text {id }}$ и $t_{\text {id }}^{\text {siдр }}$ визначають день календарного плану, на який вантаж з даної станції буде перевантажуватися на судно.

Контроль над реалізацією календарного плану здійснюється 3 диспетчерського центру регіонального транспортно-логістичного центру.

Висновок. Розроблена і описана методика календарного планування завантаження і підведення вагонів в транспортний вузол під морські судна. Необхідність розробки методики визначається недосконалістю існуючих підходів до взаємодії залізничного транспорту з морським, які грунтуються на стереотипі, що для виключення простою вагонів на підходах до порту досить забезпечити їх рівномірне підведення залізницею в кількості, що не перевищує можливості вантажнорозвантажувальних машин і механізмів порту. Разом з тим вивантаження вантажу, що прибув по залізниці здійснюється портом не в порядку його надходження, а в першу чергу при наявності (підході) судна під даний вантаж або необхідності завершення формування суднової партії.

\section{СПИСОК ЛІТЕРАТУРИ}

1. Интегрированная логистика накопительно-распределительных комплексов (склады, транспортные, терминалы): Учебник для транспортных вузов / Под ред. Л.Б. Миротина. М.: Издательство «Экзамен», 2003. 448 с.

2. Резер, С.М. Логистика экспедирования грузовых перевозок / С.М. Резер. М.: ВИНИТИ РАН, 2002. 472 c.

3. Прокофьева, Т.А. Логистика транспортно-распределительных систем: региональный аспект / Т.А. Прокофьева, О.М. Лопатин. М.: РосКонсульт, 2003. 400 c.

4. Terminology on combined transport // United Nation and Economic Commission for Europe (UN/ECE). New York and Geneva, 2001. $69 \mathrm{p}$.

5. Николашин, В.М. Основы логистики: Учебник для студентов вузов ж.-д. транспорта / В.М. Николашин, А.С. Синицына. М.: ГОУ «Учебно-методический иентр по образованию на железнодорожном транспорте», 2007. 252 c.

6. Елисеев С.Ю. Система логистического управления взаимодействием железных дорог с морскими и речными портами и другими видами транспорта / С.Ю. Елисеев. М.: ВИНИТИ PAH, 2005. $96 \mathrm{c}$. 
7. Елисеев, С.Ю. Построение и оптимизацчия функичионирования международных транспортно-логистических систем / С.Ю. Елисеев. М.: ВИНИТИ РАН, 2006. 242 c.

8. Смехов, А.А. Основы транспортной логистики / А.А. Смехов. M.: Трансnорm, 1995. 198 c.

9. Simchi-Levi, David. Designing and managing the supply chain: concepts, strategies, and case studies / David Simchi-Levi, Philip Kaminsky. New York: McGraw-Hill Companies, 2008. 496 c.

10. Куренков, П.В. Внешнеторговые перевозки в смешанном сообщении. Экономика. Логистика. Управление / П.В. Куренков, А.Ф. Котляренко. Самара: Изд-во СамГАПС, 2002. $636 \mathrm{c}$.

\section{REFERENCES}

1. Mirotina L.B. (2003)Intehrirovannaia logistika nakopitelnoraspredelitelnykh kompleksov [Integrated logistics of storage and distribution complexes]. Moscow:Ekzamen. p. 448. (in Russian).

2. Rezer S.M. (2002) Logistika espedirovaniia gruzovykh perevozok [Freight forwarding logistics]. Moscow:VINITI RAN. p. 472. (in Russian).

3. Prokofeva T.A. (2003) Logistika transportno-raspredelitelnykh system: regionalnyj aspect [Logistics of transport and distribution systems: regional aspect]. Moscow: RosKonsult. p. 400. (in Russian).

4. Terminology on combined transport(2001) // United Nation and Economic Commission for Europe (UN/ECE). New York and Genev. p. 69.

5. Nikolashin V.M. (2007) Osnovy logistiki [Logistics basics]. Moscow: GOU. p.252. (in Russian).

6. Eliseev S.Yu.(2006) Sistema logisticheskogo upravleniia vzaimodejstviem zheleznykh dorog s morskimi I rechnymi portami I drugimi vidami transporta [Logistic management system for the interaction of railways with sea and river ports and other modes of transport]. Moscow:VINITI RAN. p. 96. (in Russian).

7. Eliseev S.Yu.(2006) Postroenie $i$ optimizatsiia funktsionirovaniia mezhdunarodnykh transportno-logicheskikh system [Construction and optimization of the functioning of international transport and logical systems]. Moscow:VINITI RAN. p. 242. (in Russian).

8. Smekhov A.A. (1995) Osnovy transportnoj logistiki [Transport logistics basics]. Moscow: Transport. p. 198. (in Russian). 
ВІСНИК

ОДЕСЬКОГО НАЦІОНАЛЬНОГО

МОРСЬКОГО УНІВЕРСИТЕТУ

№ 2 (59), 2019
HERALD

OF THE ODESSA NATIONAL

MARITIME UNIVERSITY № 2 (59), 2019

9. Simchi-Levi, David. Designing and managing the supply chain: concepts, strategies, and case studies / David Simchi-Levi, Philip Kaminsky. New York: McGraw-Hill Companies, 2008. 496 c.

10. Kurenkov P.V.(2002) Vneshnetorgovye perevozki v smeshanom soobshchenii.Ekonomika. Logistika. Upravlenie. [Foreing trade in mixed traffic. Economy. Logistics. Control] Samara: SamGAPS. p.636. (in Russian).

Стаття надійшла до редакиії 21.10.2019

\section{Рецензенти:}

кандидат технічних наук, доцент, речник генерального директора стивідорної компанії ТОВ «Новотех-Термінал» Ю.І. Овсянніков

кандидат технічних наук, доцент, директор охорони праці та технологій ТОВ «Новотех-Термінал» А.О. Сверчков 